Louisiana State University

LSU Digital Commons

4-1-2015

\title{
Seasonal variation in glucocorticoid and mineralocorticoid receptors in metabolic tissues of the house sparrow (Passer domesticus)
}

Christine R. Lattin

Tufts University

L. Michael Romero

Tufts University

Follow this and additional works at: https://digitalcommons.Isu.edu/biosci_pubs

\section{Recommended Citation}

Lattin, C., \& Romero, L. (2015). Seasonal variation in glucocorticoid and mineralocorticoid receptors in metabolic tissues of the house sparrow (Passer domesticus). General and Comparative Endocrinology, 214, 95-102. https://doi.org/10.1016/j.ygcen.2014.05.033

This Article is brought to you for free and open access by the Department of Biological Sciences at LSU Digital Commons. It has been accepted for inclusion in Faculty Publications by an authorized administrator of LSU Digital Commons. For more information, please contact ir@lsu.edu. 


\title{
Seasonal variation in glucocorticoid and mineralocorticoid receptors in metabolic tissues of the house sparrow (Passer domesticus)
}

\author{
Christine R. Lattin*, L. Michael Romero \\ Department of Biology, Tufts University, Medford, MA 02155, USA
}

\section{A R T I C L E I N F O}

\section{Article history:}

Available online 11 June 2014

\section{Keywords:}

Corticosterone

Energy mobilization hypothesis

Bird

Hypothalamus-pituitary-adrenal axis

\begin{abstract}
A B S T R A C T
Glucocorticoid hormones like corticosterone (CORT) play essential metabolic roles at both baseline and stress-induced concentrations, and CORT titers vary seasonally in patterns occurring across many different vertebrate species. It has been hypothesized that CORT may vary seasonally due to changing energy requirements at different times of year. However, hormone effects are dependent on binding to receptors in target tissues, and receptors might also vary seasonally. CORT alters metabolism primarily through binding to two receptors, the high-affinity mineralocorticoid receptor (MR) and low-affinity glucocorticoid receptor (GR). We quantified GR and MR in metabolic tissues (liver, kidney, omental and subcutaneous fat, and gastrocnemius and pectoralis muscle) of wild-caught house sparrows (Passer domesticus) to assess these tissues' capacity to respond to CORT-mediated metabolic demands. We quantified receptors using radioligand binding assays in early and late winter, pre-egg-laying, breeding, late breeding and molt ( $n=12$ at each stage). MR binding did not vary significantly in any tissue over the course of the year. Because MR is associated with baseline CORT effects, this suggests that changing hormone titers may primarily regulate baseline CORT effects on metabolism. Seasonal modulation of GR binding occurred in every tissue but omental fat, though peak receptor density did not coincide with peak stress-induced CORT concentrations measured previously. Because GR is associated with stress-induced CORT effects, these data demonstrate seasonal patterns in stress-induced CORT are not driven by metabolic needs alone, although at different times of year sparrows may vary which tissue types respond to increased energy demands resulting from exposure to stressors.
\end{abstract}

(c) 2014 Elsevier Inc. All rights reserved.

\section{Introduction}

Glucocorticoid hormones such as corticosterone (hereafter CORT) serve essential metabolic roles, helping animals obtain and mobilize energy (Landys et al., 2006; Sapolsky et al., 2000). For example, at baseline concentrations, CORT promotes feeding behavior (Dallman et al., 1993); at higher concentrations, CORT shifts energy balance away from protein and fat synthesis and towards mobilization of these tissues as substrates for gluconeogenesis (Ahima and Flier, 2000; Gray et al., 1990; Hasselgren, 1999; Le Ninan et al., 1988). CORT not only exerts direct effects on metabolism, but also initiates secondary effects via other metabolic mediators such as insulin, epinephrine and neuropeptide $Y$ (la Fleur, 2006; Strack et al., 1995). There can also be differences in the effects of CORT on fed versus fasted animals (Dallman et al., 1993; Remage-Healey and Romero, 2001), as well as taxonspecific effects (Braun and Sweazea, 2008; Gleeson, 1996). This

\footnotetext{
* Corresponding author. Fax: +1 6176273805.

E-mail address: christine.lattin@tufts.edu (C.R. Lattin).
}

means that CORT does not necessarily have a single metabolic role, but rather has several metabolic roles.

In many vertebrates, CORT concentrations also vary in a predictable manner across different life history stages (Romero, 2002). For example, many species have high baseline and stress-induced CORT titers during breeding. Because of the important metabolic functions of CORT, it has been posited that CORT should be high at times of year when animals need access to more energy (the energy mobilization hypothesis as reviewed in Romero (2002)). Similarly, the concept of allostasis (McEwen and Wingfield, 2003) provides another useful energy-based framework for predicting when CORT should be high and low. Allostatic load is defined as how hard an animal must work (i.e. the amount of energy expended) to accomplish the normal tasks of each life history stage with the additional demands of coping with challenges such as infection, injury, and difficult foraging conditions (McEwen and Wingfield, 2003). We then expect the mediators of allostasis - including CORT - to wax and wane with allostatic load. Therefore, both the energy mobilization hypothesis and allostasis predict that CORT and energetic requirements will co-vary across the year. 
However, it is not clear that energetic demands should be the primary driver of CORT concentrations, especially given that physiological stress can result from many factors other than energy dysregulation (Walsberg, 2003), and that CORT has such a wide variety of functions beyond metabolism, including effects on the immune system (Spencer et al., 2001) and behavior (Moore and Orchinik, 1994; Wingfield and Silverin, 1986). Although there are certainly increased energetic costs associated with particular life history stages, such as thermoregulation in winter (Dawson and O'Connor, 1996; McNab, 2002), egg laying in female birds (Ricklefs, 1974; Williams, 2005) and pregnancy and lactation in female mammals (Kenagy, 1987; Naya et al., 2008), there is a lack of data on energetic costs across the entire spectrum of life history stages that would allow us to compare, for example, the respective costs of thermoregulation and egg laying. Furthermore, food availability, and thus the energy available in the environment, also covaries with life history stage, introducing a potential confounding factor.

Signal-receiver theory tells us that both the hormone "signal" and the receptor "receiver" are essential in creating biological effects (Csaba, 1986). Other mediators, such as the carrier protein corticosterone binding globulin, can also have important effects modulating CORT activity (Breuner et al., 2006). However, a hormone cannot have an effect without binding to a receptor, whereas not all hormonal systems include components such as binding globulins. Furthermore, CORT receptors show seasonal modulation in some tissues (Breuner and Orchinik, 2001; Lattin et al., 2013). The effects of CORT primarily occur through binding to two intracellular receptors, the high-affinity low-capacity mineralocorticoid receptor (MR), which is thought to be active even at baseline concentrations of CORT, and the low-affinity high-capacity glucocorticoid receptor (GR), which shows increased binding at the higher CORT titers resulting from the stress response (de Kloet et al., 1998; Funder, 1997). By quantifying GR and MR in metabolic tissues such as liver and muscle at different life history stages, we can assess an animal's capacity to respond to CORT-mediated baseline metabolic demands and to mobilize energy in response to stressors. GR occurs at relatively high concentrations in the metabolic tissues of both mammals (Ballard et al., 1974) and birds (Lattin et al., 2012b). Although MR concentrations in metabolic tissues are much lower in both taxa (Ballard et al., 1974; Lattin et al., 2012b), even low concentrations of MR can have important metabolic effects in mammals, for example, in fat (Caprio et al., 2007).

If seasonal patterns in CORT are primarily driven by energy demands, we would expect to see one of two patterns, depending on how this is regulated. First, this could be regulated at the level of hormone titers (Fig. 1a), as shown using CORT data from the house sparrow. In this case, we should see no seasonal variation in hormone receptors in metabolic tissues; when CORT is high, effects in metabolic tissues will be greater due to increased CORT titers. Alternatively, if this is co-regulated by both hormone titers and receptors (Fig. 1b), we should see increased receptor density in metabolic tissues at times of year when CORT is highest. Because previous work has shown that house sparrow GR and MR do not show seasonal changes in affinity (Breuner and Orchinik, 2001), these effects would be mediated by changes in receptor concentrations and/or hormone titers.

In this study, we captured wild house sparrows at six different times of year associated with important life history stages in New England: early and late winter, pre-egg-laying, breeding, late breeding and molt. Because of their widespread use in physiological studies, we already know an enormous amount about house sparrow metabolic physiology (Kuzmiak et al., 2012; Sweazea and Braun, 2006) and endocrinology of the HPA axis (Lattin et al., 2012b; Rich and Romero, 2001), making this an excellent species for further work. We used radioligand binding assays to quantify

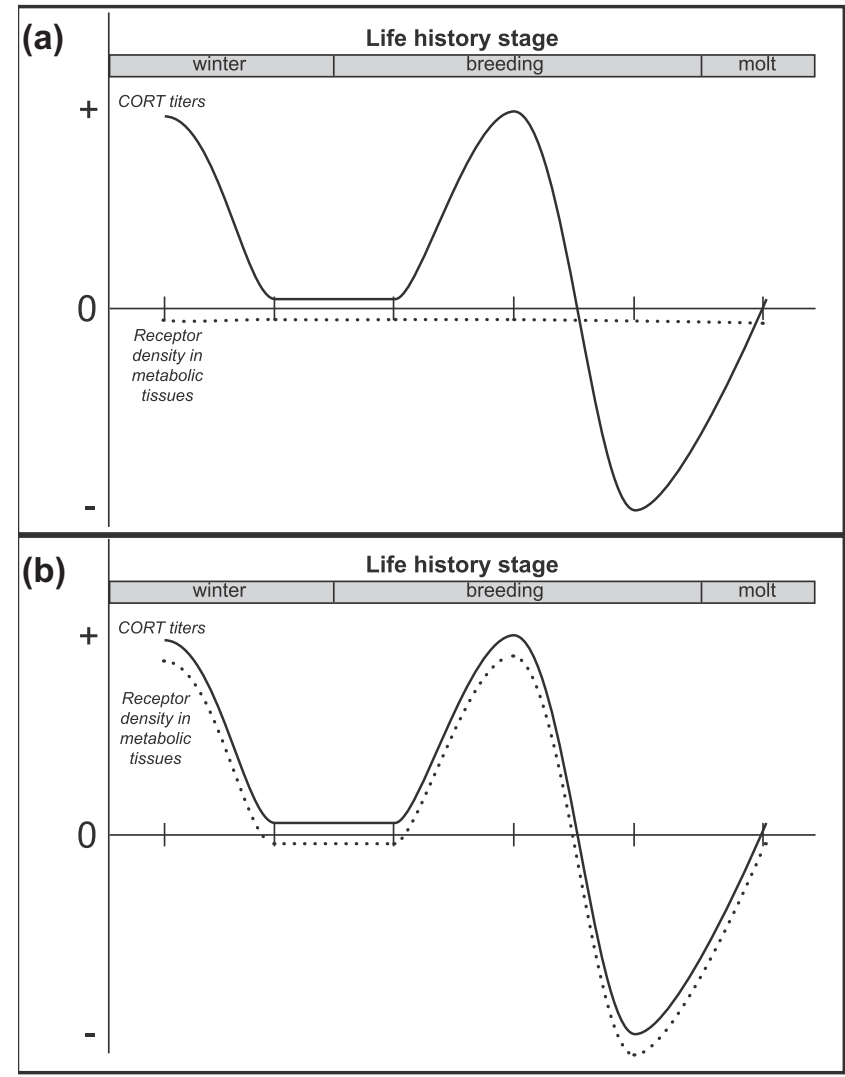

Fig. 1. If changing energy demands are the primary driver of seasonal patterns in corticosterone (CORT) titers (solid lines), we expect to see one of two patterns in receptor density in metabolic tissues at different life history stages (dotted lines). (a) If an animal meets its energy demands simply by changing its hormone titers, we will see no seasonal variation in hormone receptor density. (b) If an animal meets its energy demands by changing both its hormone titers and receptor density, we expect to see increased receptor density at times of year with high hormone titers, which could potentially even cause an amplifying effect of CORT on energy regulation. In this figure, CORT titers reflect stress-induced CORT concentrations of house sparrows in Massachusetts from an earlier study (Lattin et al., 2012a); receptor density in metabolic tissues would then be for glucocorticoid receptors, which are thought to primarily bind stress-induced CORT. In (b) lines for CORT titers and receptor density should roughly overlap and are only staggered to make them easier to see. The plus and minus signs on the $y$-axis indicate periods when the variable is above or below the annual mean.

GR and MR in tissues with metabolic functions: liver, the primary site of gluconeogenesis (Exton, 1972; Sturkie, 2000); kidney, which can be a secondary site for gluconeogenesis, particularly in fasting animals (Exton, 1972; Sturkie, 2000); muscle, which can be broken down into amino acids that serve as gluconeogenic substrates (Dallman et al., 1993; Hasselgren, 1999); and fat, which not only provides glycerol for gluconeogenesis, but is also a source of fatty acids and ketone bodies that can be used by the body directly (Baxter and Forsham, 1972; Exton, 1972). Different muscle and fat types may respond differently to CORT (Leibel et al., 1989; Yuan et al., 2008), which may be related to the roles of different muscles in locomotion or of different fat depots in energy storage. Therefore, we chose to quantify receptors in two muscle types: pectoralis, the major avian flight muscle, and gastrocnemius, a smaller muscle involved in hopping, perching, flight take-off and landing. We also chose to examine two different fat depots: subcutaneous and omental fat. In mammals, omental fat has higher concentrations of CORT receptors than subcutaneous fat (Leibel et al., 1989). This study is a continuation of previous work testing different hypotheses for seasonal regulation of CORT by examining receptor concentrations in immune tissues (Lattin et al., 2013) and in tissues involved in reproduction (Lattin and Romero, 2013). 


\section{Methods}

\subsection{Study subjects and chemical adrenalectomy}

Wild house sparrows were caught at bird feeders in Medford and Somerville MA using mist nets and Potter traps. We caught birds during molt (6-19 September 2010, $n=12$ ), early winter (12-15 December 2010, $n=12$ ), late winter (1-14 February 2011, $n=12$ ), pre-egg-laying (31 March-5 April 2011, $n=12$ ), breeding (23-24 May 2011, $n=12$ ), and late breeding (12-18 July 2011, $n=12$ ). Equal numbers of males and females were caught at each stage; only adult birds were used. All molting birds were molting primary feathers (P3-P9). We confirmed breeding stage by inspecting cloacal protuberances and beak color (in males) and brood patches (in females), and by inspecting and weighing whole gonads during sacrifice. Breeding females had significantly larger ovaries than pre-egg-laying and late breeding females, and no pre-egg-laying females had brood patches. Male beaks were significantly darker in late winter than in early winter. Additional information on breeding stage in these birds has been published elsewhere (Lattin et al., 2012a). Immediately after capture, birds were transferred to the laboratory for $36 \mathrm{~h}$ and housed in day length conditions corresponding to their capture date. All procedures involving birds were performed according to AAALAC guidelines and were approved by the Tufts University Institutional Animal Care and Use Committee.

\subsubsection{Chemical adrenalectomy}

To reduce endogenous CORT that would otherwise interfere with receptor binding assays (Breuner et al., 2000; McEwen et al., 1974), house sparrows received intramuscular injections of mitotane (ortho, para-DDD; $180 \mathrm{mg} / \mathrm{kg}$ body weight; Sigma Aldrich, St. Louis, MO) $\sim 36$ and $\sim 24$ h prior to sacrifice (Breuner and Orchinik, 2001). The necessity of surgical or chemical adrenalectomy is a limitation of the radioligand binding technique, as it is possible adrenalectomy could have an effect on receptor concentrations. However, all birds received the same mitotane treatment, and we have no a priori reason to expect that mitotane's effects on receptors would differ during different life history stages. Mitotane appears to be quite specific in reducing circulating CORT (Sanderson, 2006); for example, three days of mitotane treatment did not affect circulating testosterone or testes mass in house sparrows (Breuner et al., 2000).

To measure the success of mitotane treatment, $36 \mathrm{~h}$ after the first injection birds were restrained in cloth bags for $30 \mathrm{~min}$ and $\sim 30 \mu \mathrm{l}$ of blood was taken from the alar vein using heparinized capillary tubes. Blood samples were stored on ice until centrifugation; plasma was removed and stored at $-20^{\circ} \mathrm{C}$. We determined CORT concentrations in each sample using radioimmunoassay (RIA) following the methods of Wingfield et al. (1992). Samples were assayed in duplicate using antibody B3-163 (Esoterix, Calabasas Hills, CA), and assay values corrected for individual recoveries following extraction. Average recovery was $87 \%$ and detectability was $1 \mathrm{ng}$ CORT/ml plasma, and intra- and inter-assay coefficients of variation were $3 \%$ and $22 \%$, respectively. Mitotane reduced stress-induced CORT for all animals; mean CORT $( \pm$ SD) was $1.7 \pm 3.5 \mathrm{ng} / \mathrm{ml}$, compared to $\sim 20-30 \mathrm{ng} / \mathrm{ml}$ for house sparrows not treated with mitotane (Romero et al., 2006).

\subsection{Tissue processing}

Birds were anesthetized with intramuscular injections of ketamine ( $~ 80 \mathrm{mg} / \mathrm{kg}$ body weight; Fort Dodge Animal Health, Fort Dodge, IA) and xylazine ( $20 \mathrm{mg} / \mathrm{kg}$ body weight; Akorn, Inc., Decatur, IL), at doses appropriate for house sparrows (Muresan et al., 2008). To remove circulating corticosterone binding globulin
(Selcer and Leavitt, 1988), sparrows were transcardially perfused with ice-cold heparinized saline, and liver, right pectoralis muscle, left and right gastrocnemius, subcutaneous fat from the furcula, omental fat from the abdomen and kidneys were removed and flash-frozen on dry ice. Tissues were always taken in the same order, and the time to take all tissues was recorded for each bird (mean time $=13.5 \pm 1.3 \mathrm{~min}$ ). Tissues were stored at $-80^{\circ} \mathrm{C}$ until assay.

\subsection{Receptor binding assays}

Receptor binding assays were done following Breuner and Orchinik (2001), and have been described in detail elsewhere (Lattin et al., 2012b). We used homogenization techniques, tissue to buffer ratios, incubation times and temperatures optimized for house sparrow liver, muscle, fat and kidney (Lattin et al., 2012b). Homogenization technique, incubation time and temperature must be optimized for each tissue type to maximize specific binding and minimize non-specific binding. Because of these differences in assay technique among different tissues, receptor binding values for different tissues cannot be directly compared. Specific binding is a measure of functional protein expression, and does not necessarily correlate with mRNA expression for GR or MR (Medina et al., 2013). In all tissues but fat, assays were optimized to $\geqslant 85 \%$ specific binding; in fat, assays were optimized to $80 \%$ specific binding. Binding in individual samples was standardized per $\mathrm{mg}$ protein using Bradford assays. Each sample was run in triplicate, and for each tissue, all individuals were run in the same assay to eliminate inter-assay variation.

Briefly, whole tissues were homogenized in ice-cold buffer and spun in an ultracentrifuge to separate soluble proteins (including MR and GR) from nuclear, mitochondrial and microsomal proteins. Cytosol was incubated with $10 \mathrm{nM}\left[{ }^{3} \mathrm{H}\right] \mathrm{CORT}$ (PerkinElmer, Waltham, MA) and either (1) buffer, to measure total binding; (2) $1 \mu \mathrm{M}$ unlabeled CORT (Sigma Aldrich, St. Louis, MO), to measure non-specific binding; (3) $1 \mu \mathrm{M}$ RU486 (mifepristone; Tocris Bioscience, Minneapolis, MN), which only binds GR (Breuner and Orchinik, 2009; Lattin et al., 2012b). After subtracting out nonspecific binding, MR binding can be calculated directly from test tubes containing RU486; GR binding can be calculated by subtracting MR binding from total binding. Affinity estimates derived from previous equilibrium saturation analyses (Breuner and Orchinik, 2001; Lattin et al., 2012b) predict that $\left.10 \mathrm{nM} \mathrm{[}{ }^{3} \mathrm{H}\right] \mathrm{CORT}$ should occupy $>95 \%$ of MR and $\sim 63 \%$ of GR. Incubations were terminated by rapid filtration, and filter paper was mixed with Ultima Gold scintillation fluid (PerkinElmer, Waltham, MA) and run on a scintillation counter (TriCarb 1600, PerkinElmer/Packard, Waltham, MA).

\subsection{Data analysis}

Statistical analyses were run using JMP version 10.0 (SAS Institute Inc., 2012). Tissue mass, GR and MR binding were compared among life history stages using analysis of variance (ANOVA). We also tested for sex differences in tissue mass and GR and MR binding. In full models including sex, life history stage and possible interactions (where $n=6$ for each sex for each life history stage), we found no sex effect $(p>0.05)$ except in subcutaneous fat for GR (sex $*$ life history stage, $p=0.0014)$. Therefore, we included sex and sex $*$ life history stage interactions in the model for subcutaneous fat, but excluded sex from all other analyses. All tissues came from the same 72 birds, and we considered combining receptor analyses for all tissues in ANOVA models including individual as a random effect to account for this; however, different tissues had significantly different variances in their error terms, and this heteroscedasticity problem violates the assumptions of this type of model (Sokal and Rohlf, 1981; Zuur et al., 2009). Therefore, we ran each tissue in a separate analysis. 
With equal sample sizes, ANOVA is fairly robust to violations of normality assumptions, but not to violations of homogeneity of variances (Day and Quinn, 1989). We used Levene's test to ensure that data from each analysis met the homogeneity of variances assumption, and in situations where variances among groups were not homogeneous, ran a Welch's ANOVA (Day and Quinn, 1989). For models where we found a significant difference among groups, we ran Tukey's HSD test as a multiple comparison procedure, as recommended by Quinn and Keough (2002).

Samples containing 1-10 mg protein/mL buffer have been shown to produce accurate results for intracellular glucocorticoid receptor binding assays (López Bernal et al., 1984). Several individuals were excluded from analysis because of low protein concentrations ( $<1 \mathrm{mg}$ protein/mL buffer) in cytosol (omental fat: 1 early winter female and 1 molting female; subcutaneous fat: 1 early winter female, 1 male and 1 female in late winter and 1 pre-laying female; gastrocnemius: 1 pre-laying female, 1 late breeding male and 1 molting male). In tissue mass models, we excluded 1 early winter female from our subcutaneous fat model because she had much more fat $(223 \mathrm{mg})$ than the mean not just for her time of year ( $55 \pm 18 \mathrm{mg}$ ) but for all times of year $(58 \pm 30 \mathrm{mg})$.

Unfortunately, the body mass data for birds captured during molt were lost, so we could not control for body mass in our tissue mass analyses. However, in a previous study house sparrows caught during the same life history stages at the same locations did not show significant differences in overall body mass (Lattin et al., 2012a), making it unlikely that part-whole correlations (Christians, 1999) affected results. We also did not have sample masses available for kidney in molting birds, so did not include those in the kidney mass model.

\section{Results}

\subsection{Liver}

GR binding in liver varied by life history stage (Fig. 2; $\left.F_{5,30}=6.25, p=0.0004\right)$. Post-hoc analysis revealed that GR concentrations in liver were significantly higher during molt and early winter compared to late breeding. MR binding in liver did not vary by life history stage $\left(F_{5,66}=2.34, p=0.051\right)$. Liver mass also varied by life history stage (Table 1 ), with liver larger during molt than during early and late winter and breeding.

\subsection{Muscle}

In pectoralis, GR binding varied by life history stage (Fig. 3; $\left.F_{5,66}=3.86, p=0.0040\right)$. In this muscle type, post hoc analysis

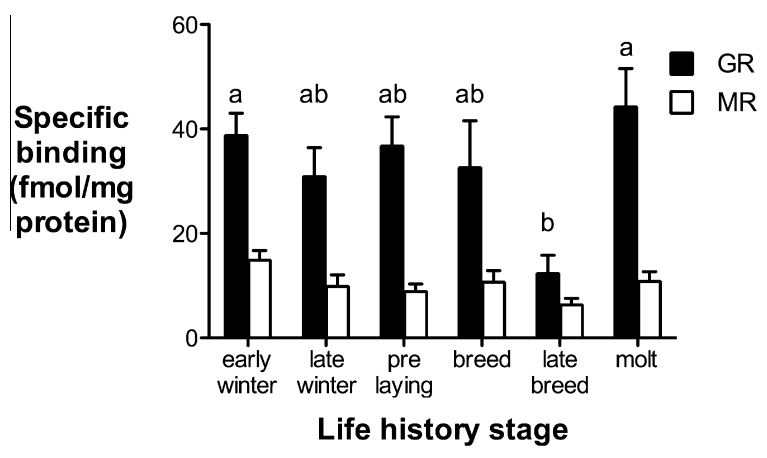

Fig. 2. Point sample analysis of glucocorticoid (GR) and mineralocorticoid (MR) receptors in the livers of house sparrows caught in Massachusetts at six different life history stages ( $n=6$ males and 6 females at each stage). Data represent means \pm SE of specific binding of $10 \mathrm{nM}\left[{ }^{3} \mathrm{H}\right] \mathrm{CORT}$ to house sparrow cytosol, standardized by protein concentration. Different letters represent statistical differences among life history stages as indicated by post hoc tests. revealed higher GR concentrations in late winter and pre-laying compared to early winter. There was no seasonal variation in MR binding in pectoralis $\left(F_{5,30}=1.96, p=0.11\right)$. GR binding in gastrocnemius also varied by life history stage (Fig. $4 ; F_{5,63}=2.89$, $p=0.021$ ); post hoc analysis revealed that GR was higher in prelaying birds than in molting birds. There was no seasonal variation in MR binding in gastrocnemius $\left(F_{5,63}=0.99, p=0.43\right)$. Both pectoralis and gastrocnemius mass varied by life history stage (Table 1 ), with muscle mass largest in late winter, pre-egg-laying and late breeding and lowest during molt for both muscle types.

\subsection{Fat}

Omental fat from around the intestines showed no seasonal variation in GR (Fig. 5; $F_{5,64}=1.53, p=0.19$ ) or $\mathrm{MR}$ binding $\left(F_{5,28}=1.41, p=0.25\right)$. GR binding did vary by life history stage and sex in subcutaneous fat from the furcular region (Fig. 6a; Overall model: $F_{11,56}=3.37, p=0.0013$; Sex: $F_{1,1}=0.21, p=0.65$; Life history stage: $F_{5,5}=3.11, \quad p=0.015 ;$ Sex $*$ life history stage: $F_{5,5}=4.82, p=0.0010$ ). Post hoc-analysis revealed that pre-laying males showed significantly increased GR binding in subcutaneous fat compared to pre-laying females and late breeding males. MR binding did not vary by life history stage (Fig. $6 \mathrm{~b} ; F_{5,62}=2.23$, $p=0.062$ ). Omental fat mass did not vary by life history stage, but subcutaneous fat mass did (Table 1), with fat mass larger in late breeding than before egg-laying.

\subsection{Kidney}

GR binding in kidney varied by life history stage (Fig. 7; $F_{5,66}=4.66, p=0.0011$ ). Post-hoc analysis revealed that kidney GR concentrations were significantly higher during late winter compared to pre-laying, breeding, molt and early winter. MR binding in kidney did not vary by life history stage $\left(F_{5,66}=0.31\right.$, $p=0.91$ ); kidney mass also did not vary by life history stage (Table 1).

\section{Discussion}

Overall, GR binding varied seasonally in many metabolic tissues from wild-caught house sparrows, whereas MR binding did not. Many of the effects of MR are permissive (i.e., priming or enhancing the effects of other physiological systems), whereas GR tends to mediate the more suppressive and stimulatory effects associated with the physiological stress response (Landys et al., 2006; Romero, 2004; Sapolsky et al., 2000). It should be noted that permissive effects of CORT on metabolism are also essential to coping with stressors - i.e., enhancing the catecholamine stimulation of glycogenolysis during the fight-or-flight response (Sapolsky et al., 2000). Therefore, across different life history stages, the permissive effects of CORT on metabolism may be primarily regulated by changing baseline CORT titers rather than by changes in MR density, whereas the suppressive and stimulatory effects of CORT on metabolism may be co-regulated by varying hormone titers and GR density in different target tissues.

However, it is important to recognize that the idea of a "twotiered" receptor system (de Kloet et al., 1990, 1998), with baseline effects mediated by high-affinity MR and stress-induced effects mediated by low-affinity GR, comes from work done in mammalian brain and may not apply to metabolic tissues in quite the same way. Furthermore, MR concentrations in the metabolic tissues of birds are quite low (Lattin et al., 2012b), suggesting these tissues may not respond strongly to changing baseline CORT titers. Also, there is some evidence that avian brain contains another receptor for CORT, which is membrane-bound and acts on a shorter time 
Table 1

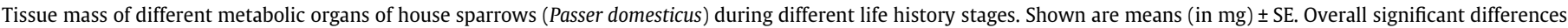

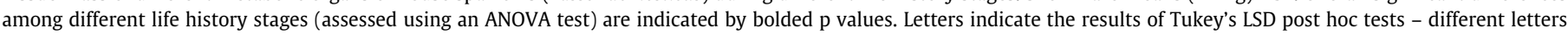
represent significant differences. Kidney masses for molting birds were not available.

\begin{tabular}{|c|c|c|c|c|c|c|c|}
\hline & Early winter & Late winter & Pre-laying & Breeding & Late breeding & Molt & ANOVA \\
\hline Liver & $629 \pm 45^{b}$ & $664 \pm 41^{\mathrm{b}}$ & $729 \pm 20^{\mathrm{ab}}$ & $687 \pm 31^{b}$ & $763 \pm 30^{\mathrm{ab}}$ & $830 \pm 32^{a}$ & $\begin{array}{l}F_{5,66}=4.58 \\
\boldsymbol{p}=\mathbf{0 . 0 0 1 2}\end{array}$ \\
\hline Pectoralis & $1524 \pm 71^{\mathrm{ab}}$ & $1783 \pm 48^{\mathrm{a}}$ & $1758 \pm 67^{a}$ & $1561 \pm 64^{\mathrm{ab}}$ & $1659 \pm 75^{\mathrm{a}}$ & $1348 \pm 75^{\mathrm{b}}$ & $\begin{array}{l}F_{5,66}=5.82 \\
\boldsymbol{p}=\mathbf{0 . 0 0 0 2}\end{array}$ \\
\hline Gastrocnemius & $166 \pm 17^{\mathrm{bc}}$ & $305 \pm 36^{a}$ & $294 \pm 31^{\mathrm{a}}$ & $246 \pm 16^{\mathrm{ab}}$ & $279 \pm 10^{\mathrm{a}}$ & $148 \pm 12^{c}$ & $\begin{array}{l}F_{5,29}=17.35 \\
\boldsymbol{p}<\mathbf{0 . 0 0 0 1}\end{array}$ \\
\hline Omental fat & $50 \pm 14$ & $43 \pm 7$ & $29 \pm 3$ & $35 \pm 6$ & $41 \pm 7$ & $25 \pm 3$ & $\begin{array}{l}F_{5,66}=1.39 \\
p=0.24\end{array}$ \\
\hline Subcutaneous fat & $55 \pm 5^{\mathrm{ab}}$ & $61 \pm 8^{\mathrm{ab}}$ & $44 \pm 6^{\mathrm{b}}$ & $62 \pm 8^{\mathrm{ab}}$ & $80 \pm 13^{a}$ & $48 \pm 6^{\mathrm{ab}}$ & $\begin{array}{l}F_{5,65}=2.42 \\
\boldsymbol{p}=\mathbf{0 . 0 4 5}\end{array}$ \\
\hline Kidney & $218 \pm 8$ & $222 \pm 8$ & $227 \pm 9$ & $228 \pm 8$ & $236 \pm 10$ & $\mathrm{~N} / \mathrm{A}$ & $\begin{array}{l}F_{4,55}=0.59 \\
p=0.67\end{array}$ \\
\hline
\end{tabular}

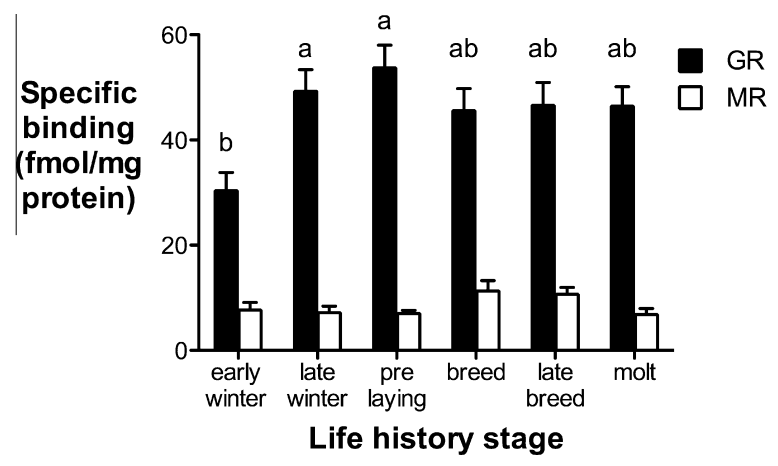

Fig. 3. Point sample analysis of glucocorticoid (GR) and mineralocorticoid (MR) receptors in the pectoralis muscle of house sparrows caught in Massachusetts at six different life history stages ( $n=6$ males and 6 females at each stage). For more information, see Fig. 2 caption.

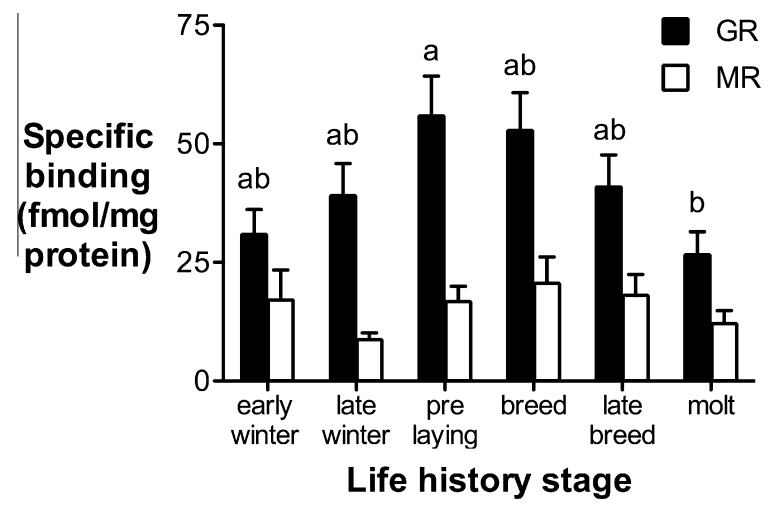

Fig. 4. Point sample analysis of glucocorticoid (GR) and mineralocorticoid (MR) receptors in gastrocnemius muscles of house sparrows caught in Massachusetts at six different life history stages $(n=6$ males and 6 females at each stage, except for missing 1 pre-laying female, 1 late breeding male and 1 molting male excluded because of low protein concentrations in cytosol). For more information, see Fig. 2 caption.

scale (Breuner and Orchinik, 2001; Breuner and Wingfield, 2000). While it is possible there are membrane-bound CORT receptors in metabolic tissues, a recent study found no evidence for this type of receptor in peripheral immune tissues (Schmidt et al., 2010).

Across different life history stages, GR binding varied in complex ways in every metabolic tissue we examined except for omental fat, as did the masses of many of the tissues (summarized in Fig. 8). However, the seasonal variation we detected in GR binding

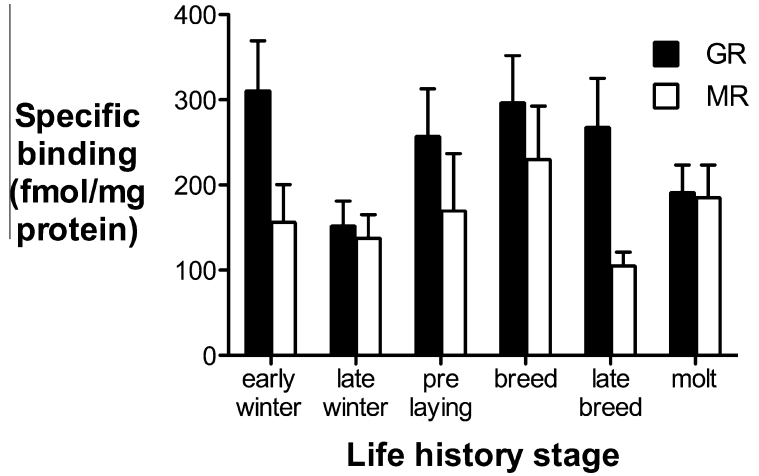

Fig. 5. Point sample analysis of glucocorticoid (GR) and mineralocorticoid (MR) receptors in omental fat from around the intestines of house sparrows caught in Massachusetts at six different life history stages $(n=6$ males and 6 females at each stage, except for missing 1 early winter female and 1 molting female excluded because of low protein concentrations in cytosol). For more information, see Fig. 2 caption.

does not provide strong support for predictions made by the energy regulation hypothesis and the allostasis model (Fig. 1). Stress-induced CORT titers were highest during early winter and breeding in house sparrows caught in the same place and at the same times as the present study (Lattin et al., 2012a). We would therefore expect to see the highest GR density in metabolic tissues during early winter and breeding if energetic demands were the key driver of seasonal CORT titers. However, early winter and breeding do not correspond with peak GR density in metabolic tissues - in fact, there is no one time of year showing peak GR binding in all metabolic tissues. Therefore, seasonal variation in stressinduced CORT is not driven by energetic demands alone, although it may certainly be one of several factors influencing the patterns we see. Hypotheses such as the preparative hypothesis, which posits that CORT concentrations should be higher at times of year associated with more frequent stressors (Romero, 2002), as well as theoretical models focusing on factors beyond energy availability, such as the reactive scope model (Romero et al., 2009), may be necessary to understand why CORT varies seasonally as it does.

However, several interesting patterns emerge upon examination of the seasonal trends in GR binding and tissue mass in metabolic tissues. Among different tissue types (Fig. 8), there are two main patterns: cases where mass and GR concentration appear to co-vary (pectoralis and gastrocnemius), and cases where as mass increases, GR density decreases, and vice versa (liver and subcutaneous fat). There is no storage form of protein as there is for carbohydrates and lipids - tissue proteins are constantly turned over by synthesis and degradation processes, which are equal when an 
(a)
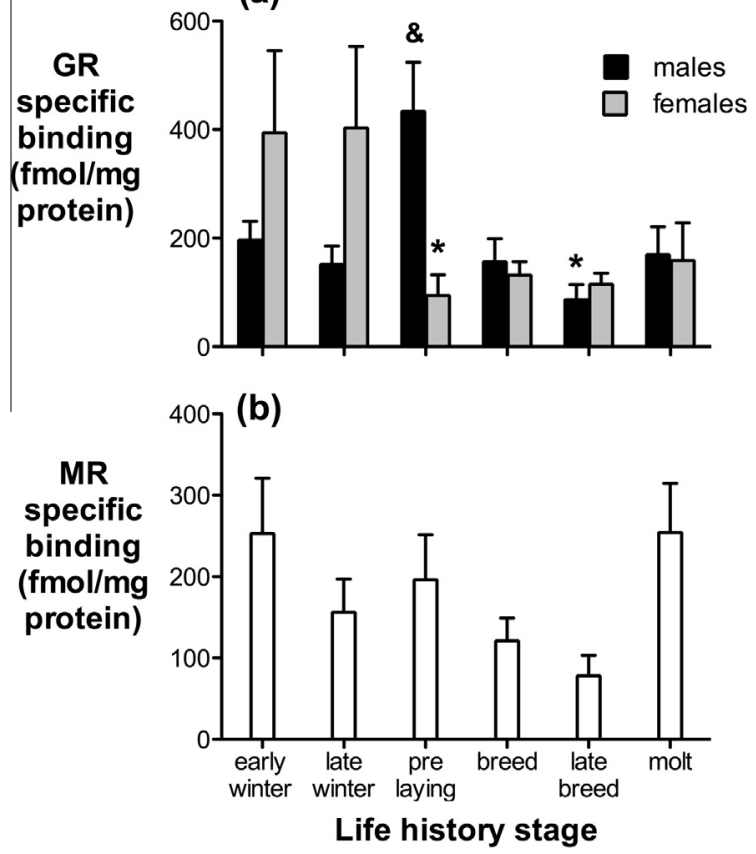

Fig. 6. Point sample analysis of (a) glucocorticoid (GR) and (b) mineralocorticoid (MR) receptors in subcutaneous fat from the furcula of house sparrows caught in Massachusetts at six different life history stages $(n=6$ males and 6 females at each stage, except for missing 1 early winter female, 1 male and 1 female in late winter and 1 pre-laying female excluded because of low protein concentrations in cytosol). The bar marked with \& indicates a significantly increased receptor concentration compared to bars marked with *. For more information, see Fig. 2 caption.

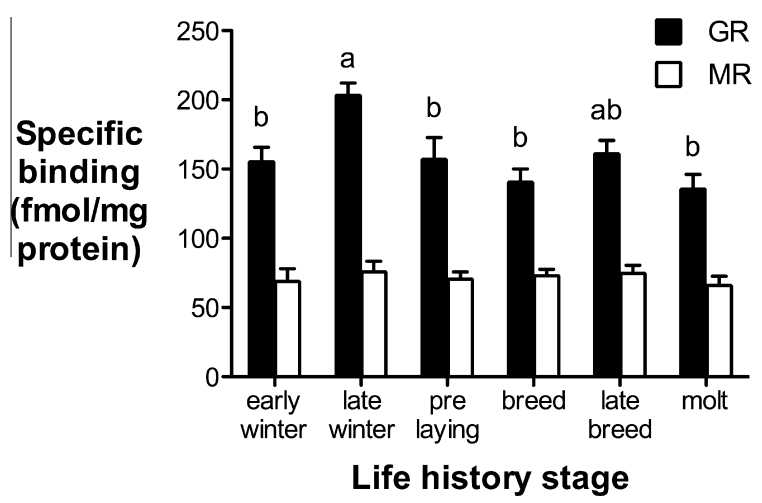

Fig. 7. Point sample analysis of glucocorticoid (GR) and mineralocorticoid (MR) receptors in the kidneys of house sparrows caught in Massachusetts at six different life history stages ( $n=6$ males and 6 females at each stage). For more information, see Fig. 2 caption.

animal is in nitrogen balance (Dohm, 1986). In the face of stressors, especially repeated or prolonged stressors, animals may need to metabolize proteins to obtain amino acids for gluconeogenesis (Hasselgren, 1999), but there are dangers in metabolizing too much protein that do not exist for fat or glycogen. Indeed, many studies involving CORT implants or CORT-laced diets demonstrate that prolonged high CORT titers cause muscle wasting (Gray et al., 1990; Tomas et al., 1979; Yuan et al., 2008); in mammals, this muscle-wasting effect is mediated by GR (Watson et al., 2012). If a sparrow mobilizes too much muscle for energy, it reduces its ability to flee unfavorable environmental conditions and future stressors. Therefore muscle GR concentrations may co-vary with muscle mass to reduce the proteolytic effects of stress-induced CORT concentrations when muscle mass is low.

We detected no major differences in the seasonal patterns of GR density or muscle mass in pectoralis compared to gastrocnemius, despite studies showing that these muscle types may respond to CORT differently, especially in birds (Honey, 1990; Yuan et al. 2008). Because the pectoralis can account for $\sim 10-25 \%$ of the total body mass of birds (Lundgren and Kiessling, 1988), some have speculated that it could be used selectively as a kind of "labile protein reserve" (Kendall et al., 1973; Ward, 1969). However, we did not see strong evidence that either muscle type would be more susceptible to mobilization by CORT through increased GR density - they appeared to be about equally susceptible.

The patterns in GR binding and tissue mass in liver and subcutaneous fat suggest that as these tissues' mass increased, sparrows decreased their capacity to mobilize these tissues for energy, and vice versa. There may be building (anabolic) and mobilizing (catabolic) phases in the life cycles of these tissues, and perhaps to build a tissue, an animal must decrease GR density in that tissue (or increase GR to mobilize it). The exception to this pattern occurred in liver during molt, when both GR density and tissue mass were high. Interestingly, many of the other metabolic tissues examined showed low GR density during molt, a time which also coincides with an overall down-regulation of the hypothalamus-pituitaryadrenal (HPA) axis in this avian species (Lattin et al., 2012a; Rich and Romero, 2001; Romero et al., 2006) as well as many others (Romero, 2002). However, in the face of chronic or prolonged stressors (such as being brought into captivity), molting birds have the ability to up-regulate HPA function in just a few days (Lattin et al., 2012a). Therefore, the increase in both GR binding and mass in liver during molt suggests that in the face of severe stressors, molting birds may rely more on carbohydrate metabolism than on protein or lipid metabolism. Indeed, in molting European starlings (Sturnus vulgaris), CORT injections resulted in hyperglycemia (Remage-Healey and Michael Romero, 2002), whereas in nonmolting starlings exogenous CORT did not change plasma glucose concentrations (Remage-Healey and Romero, 2001).

More generally, our GR binding data predict that at different times of year, wild house sparrows will vary which tissue types respond to increased energy demands resulting from exposure to stressors. Life history theory predicts that as animals pass through different, incompatible physiological states (i.e., breeding and molt), endocrine systems like the HPA axis are regulated to increase fitness within and across different stages (Ketterson and Nolan, 1992; Ricklefs and Wikelski, 2002). Therefore, patterns in GR binding in different metabolic tissues presumably help minimize conflicts between an animal's need to respond to environmental stressors and other needs, like the need to grow highquality feathers during molt (molt requires the mobilization of large amounts of protein (Murphy and King, 1990; Murphy and Taruscio, 1995), which may necessitate a shift away from protein as an emergency energy source).

Future research should focus on elucidating the relationship between potential constraints and GR density in metabolic target tissues. For example, which tissues are most responsive to stressinduced CORT titers at different times of year could be related to predictable seasonal changes in diet and food availability. Sparrows are primarily granivorous, but become more insectivorous in the summer (Lowther and Cink, 2006), which may allow in the warmer months for increased protein deposition and use of muscle as an emergency energy source. This could be tested in the lab by feeding birds low- or high-protein diets and seeing how they modulate muscle GR concentrations.

Along the same lines, it would be interesting to contrast the findings of the present study, conducted in house sparrows, with results from species with very different life history strategies 

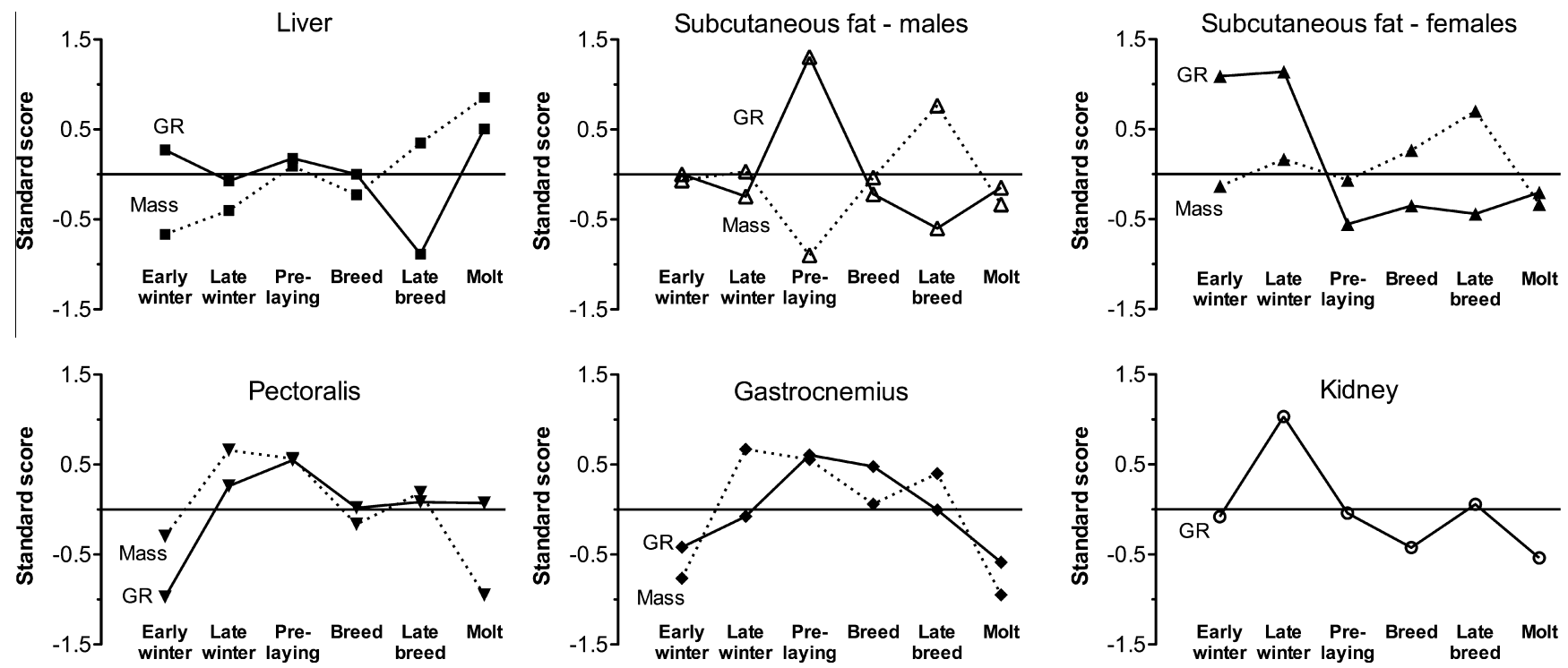

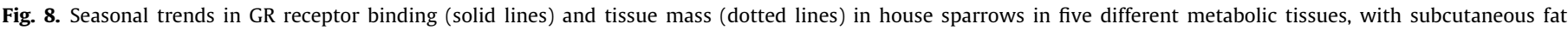

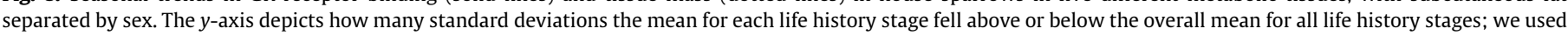

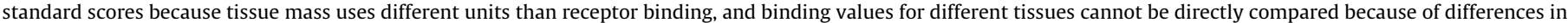

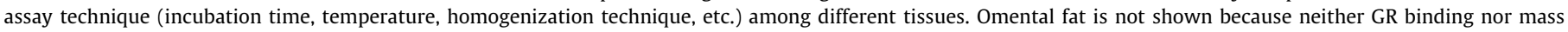
varied significantly by life history stage, and for kidney, only GR binding is shown because mass did not vary by life history stage.

(Hau et al., 2010). For example, house sparrows are non-migratory and seasonal patterns might differ in Gambel's white-crowned sparrows, which embark on long migrations and seem to rely upon GR to help mobilize lipids for fuel (Landys et al., 2004). Patterns might also differ in capital molters that drop all their feathers at once (e.g., ducks), in species with more dramatic diet changes, or in species undergoing annual hibernation periods.

To our knowledge, this work demonstrates for the first time in any species that CORT receptor density in metabolic tissues can vary seasonally. Previous studies also showed seasonal variation in CORT receptors in tissues associated with immune function (Lattin et al., 2013) and reproductive behavior (Lattin and Romero, 2013), although there too effects varied by tissue type for example, whole brain showed significant seasonal variation while ovary and testis did not. There have recently been calls to quantify performance metrics downstream of CORT such as glucose and free fatty acids (Breuner et al., 2013), and to look beyond plasma CORT titers to corticosterone binding proteins and receptors (Crespi et al., 2013). Given the complexity of the links between the HPA axis and energy regulation seen in this and other studies, we agree whole-heartedly with these calls, and encourage investigators to carefully design studies that help clarify the metabolic role of CORT at different times of year. Examining receptors in different target tissues is especially important given that hormones cannot have an effect without binding to a receptor, and, as we saw in this study, CORT receptors can be independently regulated from circulating hormone, from tissue to tissue, and even within different regions of the same tissue type.

\section{Acknowledgments}

Thank you to C. Bauer, C. Le and S. Lefebvre for providing field sites, J.M. Reed and D. Keniston for help with statistical analyses and C. Bauer and R. de Bruijn for assistance capturing and processing sparrows. Thanks also to our funding sources: the EPA STAR Fellowship program, the American Ornithologists' Union and a Tufts University Graduate Student Research Award to C.R.L. and National Science Foundation IOS-1048529 to L.M.R.

\section{References}

Ahima, R.S., Flier, J.S., 2000. Adipose tissue as an endocrine organ. Trends Endocrinol. Metabol. 11, 327-332.

Ballard, P.L., Baxter, J.D., Higgins, S.J., Rousseau, G.G., Tomkins, G.M., 1974. General presence of glucocorticoid receptors in mammalian tissues. Endocrinology 94, 998-1002.

Baxter, J.D., Forsham, P.H., 1972. Tissue effects of glucocorticoids. Am. J. Med. 53, 573-589.

Braun, E.J., Sweazea, K.L., 2008. Glucose regulation in birds. Comp. Biochem. Physiol. B 151, 1-9.

Breuner, C.W., Orchinik, M., 2001. Seasonal regulation of membrane and intracellular corticosteroid receptors in the house sparrow brain. J. Neuroendocrinol. 13, 412-420.

Breuner, C.W., Orchinik, M., 2009. Pharmacological characterization of intracellular, membrane, and plasma binding sites for corticosterone in house sparrows. Gen. Comp. Endocrinol. 163, 214-224.

Breuner, C.W., Wingfield, J.C., 2000. Rapid behavioral response to corticosterone varies with photoperiod and dose. Horm. Behav. 37, 23-30.

Breuner, C.W., Jennings, D.H., Moore, M.C., Orchinik, M., 2000. Pharmacological adrenalectomy with mitotane. Gen. Comp. Endocrinol. 120, 27-34.

Breuner, C.W., Lynn, S.E., Julian, G.E., Cornelius, J.M., Heidinger, B.J., Love, O.P., Sprague, R.S., Wada, H., Whitman, B.A., 2006. Plasma-binding globulins and acute stress response. Horm. Metab. Res. 38, 260-268.

Breuner, C.W., Delehanty, B., Boonstra, R., Fox, C., 2013. Evaluating stress in natural populations of vertebrates: total CORT is not good enough. Funct. Ecol. 27, 2436.

Caprio, M., Feve, B., Claes, A., Viengchareun, S., Lombes, M., Zennaro, M.C., 2007. Pivotal role of the mineralocorticoid receptor in corticosteroid-induced adipogenesis. FASEB J. 21, 2185-2194.

Christians, J.K., 1999. Controlling for body mass effects: is part-whole correlation important? Physiol. Biochem. Zool. 72, 250-253.

Crespi, E.J., Williams, T.D., Jessop, T.S., Delehanty, B., Boonstra, R., 2013. Life history and the ecology of stress: how do glucocorticoid hormones influence lifehistory variation in animals? Funct. Ecol. 27, 93-106.

Csaba, G., 1986. Why do hormone receptors arise? Experientia 42, 715-718.

Dallman, M.F., Strack, A.M., Akana, S.F., Bradbury, M.J., Hanson, E.S., Scribner, K.A. Smith, M., 1993. Feast and famine: critical role of glucocorticoids with insulin in daily energy flow. Front. Neuroendocrinol. 14, 303-347.

Dawson, W.R., O'Connor, T.P., 1996. Energetic features of avian thermoregulatory responses. In: Carey, C. (Ed.), Avian Energetics and Nutritional Ecology. Chapman and Hall, New York, pp. 85-124.

Day, R.W., Quinn, G.P., 1989. Comparisons of treatments after an analysis of variance in ecology. Ecol. Monogr. 59, 433-463.

de Kloet, E.R., Reul, J.M., Sutanto, W., 1990. Corticosteroids and the brain. J. Steroid Biochem. 37, 387-394.

de Kloet, E.R., Vreugdenhil, E., Oitzl, M.S., Joels, M., 1998. Brain corticosteroid receptor balance in health and disease. Endocr. Rev. 19, 269-301.

Dohm, G.L., 1986. Protein as a fuel for endurance exercise. Excerise Sport Sci. Rev. $14,143-173$. 
Exton, J.H., 1972. Gluconeogenesis. Metabolism 21, 945-990.

Funder, J.W., 1997. Glucocorticoid and mineralocorticoid receptors: biology and clinical relevance. Annu. Rev. Med. 48, 231-240.

Gleeson, T.T., 1996. Post-exercise lactate metabolism: a comparative review of sites, pathways, and regulation. Annu. Rev. Physiol. 58, 565-581.

Gray, J.M., Yarian, D., Ramenofsky, M., 1990. Corticosterone, foraging behavior, and metabolism in Dark-Eyed Juncos, Junco hyemalis. Gen. Comp. Endocrinol. 79, 375-384.

Hasselgren, P.O., 1999. Glucocorticoids and muscle catabolism. Curr. Opin. Clin. Nutr. Metab. Care 2, 201-205.

Hau, M., Ricklefs, R.E., Wikelski, M., Lee, K.A., Brawn, J.D., 2010. Corticosterone, testosterone and life-history strategies of birds. Proc. R. Soc. B 277, 3203-3212.

Honey, P.K., 1990. Avian flight muscle pectoralis major as a reserve of proteins and amino acids Zoology. University of Washington, Seattle, p. 92.

Kenagy, G.J., 1987. Energy allocation for reproduction in the golden-mantled ground squirrel. Symp. Zool. Soc. Lond. 57, 259-273.

Kendall, M.D., Ward, P., Bacchus, S., 1973. A protein reserve in the pectoralis major flight muscle of Quelea quelea. Ibis 115, 600-601.

Ketterson, E.D., Nolan, V., 1992. Hormones and life histories: an integrative approach. Am. Nat. 140 (Suppl 1), S33-S62.

Kuzmiak, S., Glancy, B., Sweazea, K.L., Willis, W.T., 2012. Mitochondrial function in sparrow pectoralis muscle. J. Exp. Biol. 215, 2039-2050.

la Fleur, S.E., 2006. The effects of glucocorticoids on feeding behavior in rats. Physiol. Behav. 89, 110-114.

Landys, M.M., Ramenofsky, M., Guglielmo, C.G., Wingfield, J.C., 2004. The lowaffinity glucocorticoid receptor regulates feeding and lipid breakdown in the migratory Gambel's white-crowned sparrow Zonotrichia leucophrys gambelii. J. Exp. Biol. 207, 143-154.

Landys, M.M., Ramenofsky, M., Wingfield, J.C., 2006. Actions of glucocorticoids at a seasonal baseline as compared to stress-related levels in the regulation of periodic life processes. Gen. Comp. Endocrinol. 148, 132-149.

Lattin, C.R., Romero, L.M., 2013. Seasonal variation in corticosterone receptor binding in brain, hippocampus and gonads in house sparrows (Passer domesticus). Auk 130, 591-598.

Lattin, C.R., Bauer, C.M., de Bruijn, R., Romero, L.M., 2012a. Hypothalamuspituitary-adrenal axis activity and the subsequent response to chronic stress differ depending upon life history stage. Gen. Comp. Endocrinol. 178, 494-501.

Lattin, C.R., Waldron-Francis, K., Richardson, J.W., de Bruijn, R., Bauer, C.M., Breuner, C.W., Romero, L.M., 2012b. Pharmacological characterization of intracellular glucocorticoid receptors in nine tissues from house sparrow (Passer domesticus). Gen. Comp. Endocrinol. 179, 214-220.

Lattin, C.R., Waldron-Francis, K., Romero, L.M., 2013. Intracellular glucocorticoid receptors in spleen, but not skin, vary seasonally in wild house sparrows (Passer domesticus). Proc. R. Soc. B 280.

Le Ninan, F., Cherel, Y., Sardet, C., Le Maho, Y., 1988. Plasma hormone levels in relation to lipid and protein metabolism during prolonged fasting in king penguin chicks. Gen. Comp. Endocrinol. 71, 331-337.

Leibel, R.L., Edens, N.K., Fried, S.K., 1989. Physiologic basis for the control of body fat distribution in humans. Ann. Rev. Nutr. 9, 417-443.

López Bernal, A., Anderson, A.B.M., Turnbull, A.C., 1984. The measurement of glucocorticoid receptors in human placental cytosol. Placenta 5, 105-116.

Lowther, P.E., Cink, C.L., 2006. House Sparrow (Passer domesticus). In: Poole, A. (Ed.), The Birds of North America Online. Cornell Lab of Ornithology, Ithaca.

Lundgren, B.O., Kiessling, K.-H., 1988. Comparative aspects of fibre types, areas, and capillary supply in the pectoralis muscle of some passerine birds with differing migratory behaviour. J. Comp. Physiol. B. 158, 165-173.

McEwen, B.S., Wingfield, J.C., 2003. The concept of allostasis in biology and biomedicine. Horm. Behav. 43, 2-15.

McEwen, B.S., Wallach, G., Magnus, C., 1974. Corticosterone binding to hippocampus: immediate and delayed influences of the absence of adrenal secretion. Brain Res. 70, 321-334.

McNab, B.K., 2002. The Physiological Ecology of Vertebrates: A View from Energetics. Cornell University Press, Ithaca, NY.

Medina, C.O., Lattin, C.R., McVey, M., Romero, L.M., 2013. There is no correlation between glucocorticoid receptor mRNA expression and protein binding in the brains of house sparrows (Passer domesticus). Gen. Comp. Endocrinol. 193, 2736.

Moore, F.L., Orchinik, M., 1994. Membrane receptors for corticosterone: A mechanism for rapid behavioral responses in an amphibian. Horm. Behav. 28, 512-519.

Muresan, C., Czirjak, G.A., Pap, P.L., Köbölkuti, L.B., 2008. Ketamine and xylazine anaesthesia in the House Sparrow. Vet. Med. 65, 193-195.

Murphy, M.E., King, J.R., 1990. Diurnal changes in tissue glutathione and protein pools of molting white-crowned sparrows: the influence of photoperiod and feeding schedule. Physiol. Zool. 63, 1118-1140.

Murphy, M.E., Taruscio, T.G., 1995. Sparrows increase their rates of tissue and whole-body protein synthesis during the annual molt. Comp. Biochem. Physiol, A 111, 385-396.
Naya, D.E., Ebensperger, L.A., Sabat, P., Bozinovic, F., 2008. Digestive and metabolic flexibility allows female degus to cope with lactation costs. Physiol. Biochem. Zool. 81, 186-194.

Quinn, G.P., Keough, M.J., 2002. Comparing groups or treatments - analysis of variance. Experimental Design and Data Analysis for Biologists. Cambridge University Press, New York, pp. 173-207.

Remage-Healey, L., Michael Romero, L., 2002. Corticosterone and insulin interact to regulate plasma glucose but not lipid concentrations in molting starlings. Gen. Comp. Endocrinol. 129, 88-94.

Remage-Healey, L., Romero, L.M., 2001. Corticosterone and insulin interact to regulate glucose and triglyceride levels during stress in a bird. Am. J. Physiol. 281, R994-R1003.

Rich, E.L., Romero, L.M., 2001. Daily and photoperiod variations of basal and stressinduced corticosterone concentrations in house sparrows (Passer domesticus). J. Comp. Physiol. B. 171, 543-547.

Ricklefs, R.E., 1974. Energetics of reproduction in birds. In: Paynter, R.A. (Ed.), Avian Energetics. Nutall Ornithology Club, Cambridge, MA, pp. 152-297.

Ricklefs, R.E., Wikelski, M., 2002. The physiology/life history nexus. Trends Ecol. Evol. 17, 462-468.

Romero, L.M., 2002. Seasonal changes in plasma glucocorticoid concentrations in free-living vertebrates. Gen. Comp. Endocrinol. 128, 1-24.

Romero, L.M., 2004. Physiological stress in ecology: lessons from biomedical research. Trends Ecol. Evol. 19, 249-255.

Romero, L.M., Cyr, N.E., Romero, R.C., 2006. Corticosterone responses change seasonally in free-living house sparrows (Passer domesticus). Gen. Comp. Endocrinol. 149, 58-65.

Romero, L.M., Dickens, M.J., Cyr, N.E., 2009. The reactive scope model - A new model integrating homeostasis, allostasis, and stress. Horm. Behav. 55, 375-389.

Sanderson, J.T., 2006. The steroid hormone biosynthesis pathway as a target for endocrine-disrupting chemicals. Toxicol. Sci. 94, 3-21.

Sapolsky, R.M., Romero, L.M., Munck, A.U., 2000. How do glucocorticoids influence stress responses? Integrating permissive, suppressive, stimulatory, and preparative actions. Endocr. Rev. 21, 55-89.

Schmidt, K.L., Malisch, J.L., Breuner, C.W., Soma, K.K., 2010. Corticosterone and cortisol binding sites in plasma, immune organs and brain of developing zebra finches: Intracellular and membrane-associated receptors. Brain Behav. Immun. 24, 908-918.

Selcer, K.W., Leavitt, W.W., 1988. Hamster uterine tissues accumulate corticosteroid-binding globulin during decidualization. Biol. Reprod. 39, 592 602.

Sokal, R.R., Rohlf, F.J., 1981. Assumptions of Analysis of Variance, Biometry, 2nd ed. W.H. Freeman, New York, NY, pp. 400-453.

Spencer, R.L., Kalman, B.A., Dhabhar, F.S., 2001. Role of endogenous glucocorticoids in immune system function: regulation and counterregulation. In: McEwen, B.S., Goodman, H.M. (Eds.), Handbook of physiology; section 7: the endocrine system, Coping with the Environment: Neural and Endocrine Mechanisms, vol IV. Oxford University Press, New York, pp. 381-423.

Strack, A.M., Sebastian, R.J., Schwartz, M.W., Dallman, M.F., 1995. Glucocorticoids and insulin: reciprocal signals for energy balance. Am. J. Physiol. 268, R142R149.

Sturkie, P.D., 2000. Sturkie's Avian Physiology, 5th. Academic Press, San Diego, CA.

Sweazea, K.L., Braun, E.J., 2006. Glucose transporter expression in English sparrows (Passer domesticus). Comp. Biochem. Physiol. B: Biochem. Mol. Biol. 144, 263-270.

Tomas, F.M., Munro, H.N., Young, V.R., 1979. Effect of glucocorticoid administration on the rate of muscle protein breakdown in vivo in rats as measured by urinary excretion of N-tau-methylhistidine. Biochem. J. 178, 139-146.

Walsberg, G.E., 2003. How useful is energy balance as a overall index of stress in animals? Horm. Behav. 43, 16-17.

Ward, P., 1969. The annual cycle of the yellow-vented bulbul, Pycnonotus goavier, in a humid equatorial environment. J. Zool. Lond. 157, 25-45.

Watson, M.L., Baehr, L.M., Reichardt, H.M., Tuckermann, J.P., Bodine, S.C., Furlow, J.D., 2012. A cell-autonomous role for the glucocorticoid receptor in skeletal muscle atrophy induced by systemic glucocorticoid exposure. Am. J. Physiol. 302, E1210-E1220.

Williams, T.D., 2005. Mechanisms underlying the costs of egg production. Bioscience 55, 39-48.

Wingfield, J.C., Silverin, B., 1986. Effect of corticosterone on territorial behavior of free-living male song sparrows Melospiza melodia. Horm. Behav. 20, 405-417.

Wingfield, J.C., Vleck, C.M., Moore, M.C., 1992. Seasonal changes of the adrenocortical response to stress in birds of the Sonoran Desert. J. Exp. Zool 264, 419-428.

Yuan, L., Lin, H., Jiang, K.J., Jiao, H.C., Song, Z.G., 2008. Corticosterone administration and high-energy feed results in enhanced fat accumulation and insulin resistance in broiler chickens. Br. Poult. Sci. 49, 487-495.

Zuur, A.F., Ieno, E.N., Walker, N.J., Saveliev, A.A., Smith, G.M., 2009. Limitations of linear regression applied on ecological data, Mixed Effects Models and Extensions in Ecology with R. Springer Science+Business Media, LLC, New York, NY, pp. 11-33. 